\title{
ANALISIS PERBANDINGAN KINERJA KEUANGAN BANK UMUM KONVENSIONAL DAN BANK SYARIAH ( STUDI 3 BUAH BANK UMUM KONVENSIONAL DAN 3 BUAH BANK UMUM SYARIAH )
}

\author{
Irfan Azwar \\ Manajemen, STIE “KBP” Padang \\ Email : $\underline{\text { Irfanazwar@yahoo.com }}$ \\ ABSTRACT
}

This study aims to compare the financial performance of conventional commercial banks with sharia commercial banks in Indonesia in the period 2012-2016 using financial ratios. The financial ratios used consist of CAR, NPL, ROA, BOPO and LDR. The type of research used in this study is quantitative research. The data used in this study are data of bank financial statements for 2012 to 2016 obtained through several websites from the bank concerned. The sampling method used was purposive sampling, based on the sample selection criteria, obtained a sample of 6 banks, 3 banks for Islamic commercial banks and 3 banks for conventional commercial banks. Data analysis techniques used to compare the performance of conventional commercial banks with Islamic commercial banks are normality test and independent sample t-test. Analysis shows that there are significant differences between the financial performance of conventional banks and Islamic banks. Based on the comparison of financial ratio analysis, conventional bank financial performance is better in terms of CAR, NPL, ROA and BOPO ratios, while the financial performance of Islamic banks is better in terms of LDR ratio.

Keywords: financial performance, conventional commercial banks and Islamic commercial banks

\section{ABSTRAK}

Penelitian ini bertujuan untuk membandingkan kinerja keuangan bank umum konvensional dengan bank umum syariah di Indonesia pada periode 2012-2016 dengan menggunakan rasio keuangan. Rasio keuangan yang digunakan terdiri dari CAR, NPL, ROA, BOPO dan LDR. Jenis penelitian yang digunakan dalam penelitian ini adalah penelitian kuantitatif. Data yang digunakan dalam penelitian ini adalah data laporan keuangan bank tahun 2012 sampai 2016 yang diperoleh melalui beberapa website dari bank yang bersangkutan. Metode pengambilan sampel yang digunakan adalah purposive sampling, Berdasarkan kriteria pemilihan sampel, diperoleh jumlah sampel sebanyak 6 bank, 3 bank untuk Bank Umum Syariah dan 3 bank untuk Bank Umum Konvensional. Teknik analisis data yang digunakan untuk membandingkan kinerja bank umum konvensional dengan bank umum syariah adalah uji normalitas dan independent sample t-test. Analisis menunjukkan bahwa terdapat perbedaan yang signifikan antara kinerja keuangan bank konvensional dengan bank syariah. Berdasarkan perbandingan analisis rasio keuangan kinerja keuangan bank konvensional lebih baik dari segi rasio CAR, NPL, ROA dan BOPO sedangkan kinerja keuangan bank syariah lebih baik dari segi rasio LDR.

Kata Kunci: Kinerja keuangan, Bank umum konvensional dan Bank umum syariah 


\section{PENDAHULUAN}

Industri perbankan di Indonesia sangat penting peranannya dalam perekonomian. Bank merupakan salah satu lembaga keuangan yang mempunyai peranan penting di dalam perekonomian suatu negara sebagai lembaga perantara keuangan. Hal ini dikarenakan perbankan merupakan salah satu dari sistem keuangan yang berfungsi sebagai (financial intermediary), yaitu suatu lembaga yang mempunyai peran untuk mempertemukan antara penyandang dan pengguna dana. Oleh karena itu, kegiatan bank harus berjalan secara efisien pada skala makro maupun mikro. Dana hasil mobilitas masyarakat dialokasikan ke berbagai ragam sektor ekonomi dan area yang membutuhkan, secara cepat dan tepat. Untuk meningkatkan mobilisasi dana masyarakat yang selama ini belum terlayani oleh sistem perbankan konvensional dan untuk mengakomodasi kebutuhan terhadap layanan jasa perbankan yang sesuai dengan prinsip syariah, maka tahun 1992 bank syariah secara resmi diperkenalkan kepada masyarakat.

Pengembangan sistem perbankan syariah di Indonesia dilakukan dalam kerangka dual-banking system atau sistem perbankan ganda dalam kerangka Arsitektur Perbankan Indonesia (API), untuk menghadirkan alternatif jasa perbankan yang semakin lengkap kepada masyarakat Indonesia. Sistem pembiayaan syariah dan perbankan konvensional dengan sinergis mendukung mobilisasi dana masyarakat secara lebih luas untuk meningkatkan kemampuan pembiayaan bagi sektor-sektor prekonomian nasional.

Periode 1992 sampai 1998, hanya terdapat satu Bank Umum Syariah dan 78 Bank Perkreditan Rakyat Syariah (BPRS) yang telah beroperasi. Tahun 1998 muncul UU No. 7 Tahun 1992 tentang perbankan. Perubahan Undang-Undang tersebut menimbulkan beberapa perubahan yang memberikan peluang yang lebih besar bagi pengembangan bank syariah. Undang-Undang tersebut telah mengatur secara rinci landasan hukum serta jenis-jenis usaha yang dapat dioperasikan dan diimplementasikan oleh bank syariah. Undang-Undang tersebut juga memberikan arahan bagi bank-bank konvensional untuk membuka cabang syariah atau bahkan mengkonversikan diri untuk secara total menjadi bank syariah (Maharani, 2010).

Bunga atau riba adalah penambahan, perkembangan peningkatan dan pembesaran yang diterima oleh pemilik dana, sebagai suatu imbalan karena menangguhkan atau berpisah dari sebagian modalnya selama periode waktu tertentu. Secara umum riba adalah pengembalian tambahan yang harus dibayar, baik dalam transaksi jual beli maupun sewa menyewa yang bertentangan dengan prinsip syariah ( Antonio, 2001).

Menurut Kasmir (2011:11), pengertian bank yaitu lembaga keuangan yang kegiatan utamanya adalah menghimpun dana dari masyarakat serta memberikan jasa bank lainnya. Menurut Undang-Undang Nomor 7 Tahun 1992 dan ditegaskan lagi dengan keluarnya Undang-Undang Republik Indonesia Nomor 10 Tahun 1998, jenis perbankan terdiri dari 2 (dua) yakni (Kasmir,2007):

Bank Umum adalah bank yang melaksanakan kegiatan usahanya secara konvensional dan atau berdasarkan prinsip syariah yang dalam kegiatannya memberikan jasa dalam lalu lintas pembayaran. Sifat jasa yang diberikan adalah 
umum, dalam arti bahwa bank ini dapat memberikan seluruh jasa perbankan yang ada.

Bank Perkreditan Rakyat (BPR) adalah bank yang melaksanakan kegiatan usahanya secara konvensional dan atau berdasarkan prinsip syariah yang dalam kegiatannya tidak memberikan jasa dalam lalu lintas pembayaran. Artinya, kegiatan BPR jauh lebih sempit dibandingkan dengan kegiatan bank umum.

Fungsi bank adalah menghimpun dana dari masyarakat dan menyalurkan kembali dana tersebut kepada masyarakat lain yang memerlukan. Masyarakat menghimpun dana di bank untuk mencari keuntungan berdasarkan bunga. Jadi kedua belah pihak mendapat keuntungan. Masyarakat yang menghimpun dananya akan mendapatkan imbalan berdasarkan prinsip bunga. Berikut akan dijelaskan tentang konsep-konsep penghimpunan dana pada bank konvensional. Dalam menghimpun dana, bank syariah melakukan mobilisasi dan investasi tabungan dengan cara yang adil sehingga keuntungan yang adil dapat dijamin bagi semua pihak. Tujuan mobilisasi dana merupakan hal yang penting karena Islam secara tegas mengutuk penimbunan tabungan dan menuntut penggunaan sumber dana secara produktif dalam rangka mencapai tujuan sosial ekonomi Islam. Berkaitan dengan hal di atas, maka prinsip yang dianut bank syariah dalam menghimpun dana adalah, sebagai berikut:

Tabel 1

Prinsip Produk Dana

\begin{tabular}{|c|c|c|c|}
\hline No & Produk & Prinsip & Return untuk nasabah \\
\hline 1 & Giro & Wadiah(titipan) & $\begin{array}{l}\text { Bonus sesuai kehendak } \\
\text { bank }\end{array}$ \\
\hline 2 & Tabungan & $\begin{array}{l}\text { Wadiah(titipan), } \\
\text { Mudharabah (bagi hasil) }\end{array}$ & $\begin{array}{l}\text { Bonus sesuai dengan } \\
\text { kehendak bank, bagi } \\
\text { hasil dengan nisbah }\end{array}$ \\
\hline 3 & Deposito & $\begin{array}{l}\text { Mudharabah } \\
\text { Muthlaqah, } \\
\text { Mudharabah } \\
\text { Muqayyadah }\end{array}$ & $\begin{array}{lr}\text { Bagi hasil dengan } \\
\text { nisbah, bagi hasil } \\
\text { dengan nisbah }\end{array}$ \\
\hline 4 & Obligasi/Sukuk & $\begin{array}{l}\text { Mudharabah } \\
\text { Ijarah }\end{array}$ & 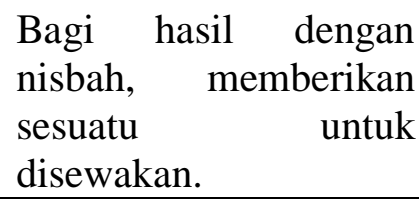 \\
\hline
\end{tabular}

Laporan keuangan merupakan media yang dapat dipakai untuk meneliti kondisi kesehatan perusahaan yang terdiri atas neraca, perhitungan laba rugi, ikhtisar laba yang ditahan dan dilaporkan dan di laporan posisi keuangan. Laporan keuangan pada prinsipnya merupakan salah satu pertanggungjawaban manajemen atas sumber daya yang dipercayakan kepadanya. Laporan keuangan adalah produk atau hasil akhir dari suatu proses akuntansi. Laporan keuangan inilah yang menjadi bahan informasi bagi para pemakainya sebagai salah satu bahan dalam proses pengambilan keputusan. Dengan demikian, laporan 
keuangan dapat dijadikan sebagai sumber informasi utama oleh berbagai pihak untuk menilai kinerja manajemen sekaligus kinerja ekonomi perusahaan.

Evaluasi terhadap laporan keuangan dilakukan oleh para pemakainya untuk pengambilan keputusan sesuai dengan kepentingan mereka masing-masing. Di samping sebagai informasi, laporan keuangan juga sebagai pertanggungjawaban dan juga dapat menggambarkan indikator kesuksesan suatu perusahaan mencapai tujuannya (Sawir, 2005:02). Menurut (Sofyan Harahap), laporan keuangan adalah media informasi yang mencakup semua aktivitas perusahaan. Jika informasi ini disajikan dengan benar maka informasi tersebut sangat berguna bagi siapa saja untuk mengambil keputusan tentang perusahaan yang dilaporkan tersebut. Laporan keuangan yang umum dikenal yaitu :

Daftar neraca yang menggambarkan posisi keuangan perusahaan pada satu tanggal tertentu. Neraca menggambarkan posisi harta, utang, dan modal pada tanggal tertentu. Harta (aset) yang disebut juga aktiva adalah merupakan harta produktif yang dikelola dalam perusahaan tersebut, dan aset ini diperoleh dari sumber utang atau modal (Yusuf \& Yusra, 2019). Sumber pendanaan aset adalah utang jangka panjang, jangka pendek, atau berasal dari modal pemilik (Hanafi \& Yusra, 2019; Yusra, Hadya, \& Fernandes, 2017).

Perhitungan laba-rugi yang menggambarkan jumlah hasil, biaya dan laba/rugi perusahaan pada suatu periode tertentu. Laba rugi menggambarkan hasil yang diterima selama satu periode tertentu serta biaya-biaya yang dikeluarkan untuk mendapatkan hasil tersebut. Hasil dikurangi biaya-biaya merupakan laba atau rugi. Jika hasil lebih besar dari biaya berarti laba, sebaliknya jika hasil lebih kecil dari biaya berarti rugi. Laporan sumber dan penggunaan dana, di sini dimuat sumber dana dan pengeluaran perusahaan selama satu periode.

Laporan arus kas, di sini disajikan informasi tentang dari mana sumber kas diperoleh dan untuk ke mana kas dipergunakan. Disamping itu, ada lagi laporan tambahan (supporting statement) seperti harga pokok produksi, laporan perubahan modal, laporan laba ditahan. Kemudian dilengkapi lagi dengan catatan dan penjelasan laporan keuangan yang merupakan bagian yang tidak terpisahkan dari laporan keuangan utama (Harahap, 2002). Perkembangan suatu perusahaan sangat perlu untuk megetahui kondisi keuangan perusahaan yang bersangkutan yang terdiri atas neraca, laporan perhitungan laba rugi, serta laporan-laporan keuangan lainnya. Dengan mengadakan analisis laporan keuangan terhadap pos-pos neraca akan dapat diketahui atau diperoleh gambaran kinerja posisi keuangannya, sedangkan analisis terhadap laporan laba rugi, labanya akan memberikan gambaran tentang hasil atau perkembangan usaha perusahaan yang bersangkutan.

Ukuran yang sering digunakan dalam analisis laporan keuangan adalah rasio. Rasio yang biasa digunakan dalam hal untuk mengukur kinerja keuangan bank adalah rasio solvabilitas (kecukupan modal), rasio profitabilitas, dan rasio likuiditas (Danil \& Yusra, 2019; Kurniawan \& Yusra, 2019; Yusra, 2016). Penilaian keputusan berinvestasi dalam pasar modal dan menilai sehat atau tidaknya suatu perusahaan, biasanya yang dinilai adalah kinerja keuangan perusahaan yang bersangkutan. Kinerja keuangan suatu perusahaan dapat 
dinilai berdasarkan analisis laporan keuangan maupuan analisis rasio keuangan perusahaan yang bersangkutan.

Salah satu cara untuk mendeteksi kesehatan suatu perusahaan, masalah-masalah yang sedang dihadapinya termasuk mengenai kinerjanya adalah melalui analisis rasio-rasio keuangannya. Analisis rasio adalah cara menganalisis dengan menggunakan perhitungan-perhitungan perbandingan data kuantitatif yang ditunjukkan dalam Neraca atau Laporan Laba Rugi Perusahaan (Kuswadi, 2006). Menurut Faisal Abdullah, pengertian analisis rasio keuangan adalah teknik analisis untuk mengetahui hubungan antara pos-pos tertentu dalam neraca maupun laporan laba rugi, baik secara individu maupun secara simultan (Abdullah, 2003:108)

Bank konvensional dan bank syariah dalam beberapa hal memiliki persamaan, terutama dalam sisi teknis penerimaan uang, mekanisme transfer, teknologi komputer yang digunakan, persyaratan umum pembiayaan, dan lain sebagainya. Perbedaan antara bank konvensional dan bank syariah menyangkut aspek legal, struktur organisasi, usaha yang dibiayai, dan lingkungan kerja (Ningsih, 2012).

\section{Tabel 2}

Perbedaan Bank Konvensional dengan Bank Syariah

\begin{tabular}{|c|c|c|}
\hline Keterangan & Bank Syariah & $\begin{array}{c}\text { Bank } \\
\text { Konvensional }\end{array}$ \\
\hline $\begin{array}{l}\text { Akad dan aspek } \\
\text { legalitas }\end{array}$ & $\begin{array}{l}\text { Hukum Islam dan } \\
\text { hukum positif }\end{array}$ & Hukum positif \\
\hline $\begin{array}{l}\text { Lembaga penyelesaian } \\
\text { sengketa }\end{array}$ & $\begin{array}{l}\text { Badan Arbitrase } \\
\text { Muamalat Indonesia } \\
\text { (BAMUI) }\end{array}$ & $\begin{array}{l}\text { Badan Arbitrase } \\
\text { Nasional } \\
\text { Indonesia (BAN) }\end{array}$ \\
\hline Struktur organisasi & $\begin{array}{l}\text { Ada Dewan Syariah } \\
\text { Nasional (DSN) dan } \\
\text { Dewan Pengawas } \\
\text { Syariah (DPS) }\end{array}$ & $\begin{array}{l}\text { Tidak ada DSN } \\
\text { dan DPS }\end{array}$ \\
\hline Investasi & Halal & Halal dan haram \\
\hline Prinsip organisasi & $\begin{array}{l}\text { Bagi hasil, jual beli, } \\
\text { sewa }\end{array}$ & Perangkat bunga \\
\hline Tujuan & $\begin{array}{l}\text { Profit dan falah } \\
\text { oriented }\end{array}$ & Profit oriented \\
\hline Hubungan nasabah & Kemitraan & Debitur-kreditur \\
\hline
\end{tabular}

\section{METODE PENELITIAN}

Jenis penelitian yang ada dalam penelitian ini adalah dengan menggunakan analisis pendekatan kuantitatif. Penelitian ini menggunakan data kuantitatif karena penilitian ini bersifat menganalisis kinerja keuangan dan menghitung data yang merupakan kinerja laporan keuangan pada perusahaan perbankan yang terdaftar di Bursa Efek Indonesia (BEI).

Objek penelitian adalah suatu yang menjadi perhatian dalam suatu penelitian atau tempat / lokasi dimana seseorang meneliti sebuah riset. Objek dalam penelitian ini adalah Bank Konvensional dan Bank syariah yang diketahui melalui website Bank Indonesia. 
Populasi dalam penelitian ini adalah seluruh Bank Konvensional dan Bank Syariah yang terdaftar di Bank Indonesia. Metode yang digunakan dalam pengambilan sampel ini adalah dengan menggunakan metode purposive sampling, yaitu sampel diambil berdasarkan kriteria-kriteria tertentu. Kriteria untuk pemilihan sampel yang akan diteliti dalam penelitian ini adalah sebagai berikut:

Tabel 3

Kriteria Dalam Pemilihan Sampel

\begin{tabular}{ll}
\hline \multicolumn{1}{c}{ Bank Umum Syariah } & \multicolumn{1}{c}{ Bank Umum Konvensional } \\
\hline Merupakan bank yang telah berdiri & Merupakan Bank BUMN \\
selama kurang lebih 5 tahun & Merupakan bank yang telah berdiri \\
Merupakan bank yang terkenal di & selama kurang lebih 5 tahun \\
masyarakat & Merupakan bank yang terkenal di \\
Merupakan bank yang memiliki outlet & masyarakat \\
terbanyak & Merupakan bank yang memiliki \\
& jumlah outlet terbanyak \\
& Merupakan bank yang memiliki \\
& jumlah nasabah terbanyak
\end{tabular}

Sumber : Hasil Olahan Sendiri, 2018

Berdasarkan kriteria pemilihan sampel di atas, diperoleh jumlah sampel sebanyak 6 bank, 3 bank untuk Bank Umum Syariah (PT Bank Syariah Mandiri Tbk, PT. BRI Syariah Tbk dan PT BNI Syariah Tbk.), dan 3 bank untuk Bank Umum Konvensional ( PT Bank Mandiri Tbk, PT. BRI Tbk dan PT BNI Tbk). Dalam penelitian ini, penulis melakukan analisis untuk melihat perbandingan kinerja keuangan antara bank konvensional dan bank syariah di Indonesia selama periode tahun 2012-2016. Sumber data dalam penelitian ini diperoleh dari data sekunder. Tahap ini dilakukan dengan cara mengumpulkan data-data sekunder berupa Laporan Keuangan Publikasi Bank selama periode yang telah ditentukan. Data yang diperoleh diambil melalui beberapa website dari bank yang bersangkutan dan Perpustakaan Bank Indonesia. Jenis laporan yang digunakan antara lain Neraca Keuangan, Laporan Laba-Rugi, Laporan Kualitas Aktiva produktif, Perhitungan Kewajiban Penyediaan Modal Minimum dan Ikhtisar keuangan. Tahapan dalam analisis data menggunakan uji normalitas dan Independent sample t test.

Definisi operasional variabel pada penelitian ini adalah rasio keuangan yang terdiri dari Capital Adequacy Ratio (CAR) yang mewakili rasio permodalan, Non Performing Loan (NPL) yang mewakili rasio kualitas aktiva produktif, Return on Asset (ROA) yang mewakili rasio rentabilitas, Beban Operasional dibagi Pendapatan Operasional (BOPO) yang mewakili rasio efisiensi, dan Loan to Deposit Ratio (LDR) yang mewakili rasio likuiditas. 
Tabel 4

Definisi Operasional Variabel

\begin{tabular}{|c|c|c|}
\hline Variabel & Konsep & Indikator \\
\hline $\begin{array}{l}\text { Permodalan } \\
\text { (CAR) } \\
\text { (X1) }\end{array}$ & $\begin{array}{l}\text { CAR adalah rasio yang } \\
\text { digunakan untuk mengukur } \\
\text { proprsi modal sendiri } \\
\text { dibandingkan dana luar } \\
\text { dalam } \\
\text { pembiayaan kegiatan usaha } \\
\text { perbankan. Aturan baru dari } \\
\text { Bank Indonesia CAR } \\
\text { minimum bagi setiap } \\
\text { perbankan nasional adalah } \\
8 \% \text {. (Ningsih, 2012) }\end{array}$ & CAR $=\frac{\text { Total Modal }}{\text { ATMR }}$ \\
\hline $\begin{array}{l}\text { Kualitas } \\
\text { Asset } \\
(\mathrm{X} 2)\end{array}$ & $\begin{array}{l}\text { NPL adalah untuk melihat } \\
\text { seberapa besar tingkat kredit } \\
\text { bermasalah yang telah } \\
\text { disalurkan oleh bank. Bank } \\
\text { Indonesia memberikan aturan } \\
\text { baku }\end{array}$ & 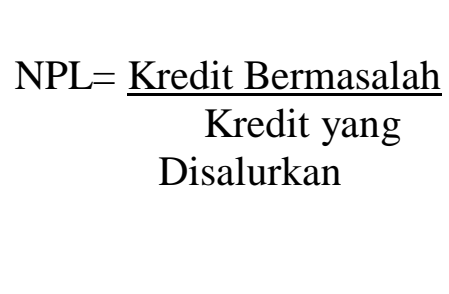 \\
\hline $\begin{array}{l}\text { Rentabilitas } \\
\text { (X3) }\end{array}$ & $\begin{array}{l}\text { ROA untuk mengukur } \\
\text { kemampuan manajemen bank } \\
\text { dalam memperoleh } \\
\text { keuntungan secara } \\
\text { keseluruhan. (Ningsih, 2012) }\end{array}$ & ROA $=\frac{\text { Laba setelah pajak }}{\text { Total Aktiva }}$ \\
\hline $\begin{array}{l}\text { Efisiensi } \\
\text { (X4) }\end{array}$ & $\begin{array}{l}\text { BOPO untuk mengukur } \\
\text { tingkat efisiensi dan } \\
\text { kemampuan bank dalam } \\
\text { melakukan kegiatan } \\
\text { operasionalnya. (Ningsih, } \\
\text { 2012) }\end{array}$ & $\begin{array}{r}\mathrm{BOPO}=\text { Biaya Operasi } \\
\text { Pendapatan Operasi }\end{array}$ \\
\hline $\begin{array}{l}\text { Likuiditas } \\
\text { (X5) }\end{array}$ & $\begin{array}{l}\text { LDR adalah rasio antara } \\
\text { seluruh jumlah kredit yang } \\
\text { diberikan bank dengan dana } \\
\text { yang diterima oleh bank. } \\
\text { (Ningsih, 2012) }\end{array}$ & $\begin{array}{l}\text { LDR }=\text { Total Kredit yang } \\
\frac{\text { diberikan }}{\text { Dana Pihak Ketiga }}\end{array}$ \\
\hline
\end{tabular}




\section{HASIL PENELITIAN}

Persaingan yang terjadi mengakibatkan akan upaya dari nasabah untuk pengalihan dana masyarakat yang diakibatkan naik ataupun turun tingkat suku bunga, masyarakat akan lebih memilih menabung di bank syariah. Sabaliknya terjadinya tingkat bunga yang menguntungkan nasabah maka masyarakat akan menabung ke bank-bank konvensional. Adapun bentuk kegiatan bank syariah serta perbankan konvensional disaksikan di tabel ini.

Tabel 5

Kinerja Keungan Bank Konvensional

\begin{tabular}{|c|c|c|c|c|c|c|}
\hline \multirow{2}{*}{ Kode Bank } & \multirow{2}{*}{ Tahun } & \multicolumn{5}{|c|}{ Rasio Keuangan } \\
\hline & & CAR & NPL & ROA & BOPO & LDR \\
\hline \multirow{5}{*}{$\begin{array}{l}\text { Bank } \\
\text { Mandiri }\end{array}$} & 2012 & $15.48 \%$ & $1.74 \%$ & $3.55 \%$ & $63.93 \%$ & $77.66 \%$ \\
\hline & 2013 & $14.93 \%$ & $1.60 \%$ & $3.66 \%$ & $62.41 \%$ & $82.97 \%$ \\
\hline & 2014 & $16.60 \%$ & $1.66 \%$ & $3.57 \%$ & $64.98 \%$ & $82.02 \%$ \\
\hline & 2015 & $18.60 \%$ & $2.29 \%$ & $3.15 \%$ & $69.67 \%$ & $87.05 \%$ \\
\hline & 2016 & $21.36 \%$ & $3.96 \%$ & $1.95 \%$ & $80.94 \%$ & $85.86 \%$ \\
\hline \multirow{5}{*}{$\begin{array}{l}\text { Bank } \\
\text { Negara } \\
\text { Indonesia } \\
\text { (BNI) }\end{array}$} & 2012 & $16.67 \%$ & $2.84 \%$ & $2.92 \%$ & $70.99 \%$ & $77.52 \%$ \\
\hline & 2013 & $15.09 \%$ & $2.17 \%$ & $3.36 \%$ & $67.09 \%$ & $85.30 \%$ \\
\hline & 2014 & $16.22 \%$ & $1.96 \%$ & $3.49 \%$ & $68.02 \%$ & $87.81 \%$ \\
\hline & 2015 & $19.49 \%$ & $2.70 \%$ & $2.64 \%$ & $75.48 \%$ & $87.77 \%$ \\
\hline & 2016 & $19.36 \%$ & $2.96 \%$ & $2.69 \%$ & $73.59 \%$ & $90.41 \%$ \\
\hline \multirow{5}{*}{$\begin{array}{l}\text { Bank } \\
\text { Rakyat } \\
\text { Indonesia } \\
\text { (BRI) }\end{array}$} & 2012 & $16.95 \%$ & $1.78 \%$ & $5.15 \%$ & $59.93 \%$ & $79.85 \%$ \\
\hline & 2013 & $16.99 \%$ & $1.55 \%$ & $5.03 \%$ & $60.58 \%$ & $88.54 \%$ \\
\hline & 2014 & $18.31 \%$ & $1.69 \%$ & $4.74 \%$ & $65.37 \%$ & $81.68 \%$ \\
\hline & 2015 & $20.59 \%$ & $2.02 \%$ & $4.19 \%$ & $67.96 \%$ & $86.88 \%$ \\
\hline & 2016 & $22.91 \%$ & $2.03 \%$ & $3.84 \%$ & $68.93 \%$ & $87.77 \%$ \\
\hline
\end{tabular}

Sumber: Laporan Keuangan Masing-masing Bank

Dari tabel diatas menunjukkan bahwa kinerja keuangan bank konvensional masing-masing rasio keuangan berfluktuasi. Dari sisi permodalan, secara umum bank konvensional memiliki permodalan yang cukup baik untuk memenuhi kewajiban jangka panjangnya, hal ini dapat dilihat dari permodalan yang dimiliki bank konvensional diatas standar yang telah ditentukan oleh Bank Indonesia. Besar modal yang harus disediakan oleh bank sangat bergantung pada seberapa besar risiko yang dihadapi oleh bank tersebut. Nilai rasio CAR tertinggi yaitu pada Bank BRI tahun 2016 sebesar $22.91 \%$, sedangkan nilai CAR paling rendah yaitu pada Bank Mandiri tahun 2013 sebesar $14.93 \%$.

Pada rasio kualitas aktiva, kinerja bank konvensional yang baik hal ini tercermin dari nilai NPL yang bersifat fluktuatif dan telah memenuhi standar Bank Indonesia yaitu dibawah 5\%. Nilai rasio NPL tertinggi yaitu pada Bank Mandiri tahun 2016 sebesar 3.96\%, sedangkan nilai NPL yang paling rendah yaitu pada Bank BRI tahun 2013 sebesar 1.55\%. pada raio rentabilitas, pada umumnya bank konvensional memiliki kemampuan menghasilkan laba yang memadai, hal ini dapat dilihat dari laba yang diperoleh yaitu pada rasio ROA melebihi standar oleh Bank Indonesia dan 
mendukung peningkatan modal bank. Nilai rasio ROA tertinggi yaitu pada Bank BRI tahun 2012 sebesar 5.15\%, sedangkan nilai ROA terendah yaitu pada Bank Mandiri tahun 2016 sebesar 1.95\%.

Selanjutnya pada rasio efisiensi perbankan, yaitu rasio BOPO bank konvensional masih berada pada standar yang ditetapkan oleh bank Indonesia. Terakhir yaitu rasio likuiditas, dengan menggunakan LDR yaitu kemampuan bank dalam membayar kembali kepada nsabah yang telah menanamkan dananya dengan kredit-kredit yang telah diberikan kepada debiturnya. Nilai rasio LDR tertinggi yaitu pada Bank BNI tahun 2016 sebesar $90.41 \%$ sedangkan rasio terendah yaitu pada Bank BNI tahun 2012 sebesar $77.52 \%$.

\section{Tabel 6}

Kinerja Keuangan Bank Syariah

\begin{tabular}{|c|c|c|c|c|c|c|}
\hline \multirow{2}{*}{ Kode Bank } & \multirow{2}{*}{ Tahun } & \multicolumn{5}{|c|}{ Rasio Keuangan } \\
\hline & & CAR & NPL & ROA & BOPO & LDR \\
\hline \multirow{5}{*}{$\begin{array}{l}\text { Bank } \\
\text { Syariah } \\
\text { Mandiri }\end{array}$} & 2012 & $13.82 \%$ & $2.82 \%$ & $2.25 \%$ & $73.00 \%$ & $94.40 \%$ \\
\hline & 2013 & $14.10 \%$ & $4.32 \%$ & $1.53 \%$ & $84.03 \%$ & $89.37 \%$ \\
\hline & 2014 & $14.76 \%$ & $6.84 \%$ & $0.17 \%$ & $98.46 \%$ & $82.13 \%$ \\
\hline & 2015 & $12.85 \%$ & $6.06 \%$ & $0.56 \%$ & $94.78 \%$ & $81.99 \%$ \\
\hline & 2016 & $14.01 \%$ & $4.92 \%$ & $0.59 \%$ & $94.12 \%$ & $79.19 \%$ \\
\hline \multirow{5}{*}{$\begin{array}{l}\text { Bank } \\
\text { Negara } \\
\text { Indonesia } \\
\text { Syariah } \\
\text { (BNI S) }\end{array}$} & 2012 & $19.07 \%$ & $2.02 \%$ & $1.48 \%$ & $85.39 \%$ & $84.99 \%$ \\
\hline & 2013 & $16.23 \%$ & $1.86 \%$ & $1.37 \%$ & $83.94 \%$ & $97.86 \%$ \\
\hline & 2014 & $18.42 \%$ & $1.86 \%$ & $1.27 \%$ & $85.03 \%$ & $92.58 \%$ \\
\hline & 2015 & $15.48 \%$ & $2.53 \%$ & $1.43 \%$ & $89.63 \%$ & $91.94 \%$ \\
\hline & 2016 & $14.92 \%$ & $2.94 \%$ & $1.44 \%$ & $86.88 \%$ & $84.57 \%$ \\
\hline \multirow{5}{*}{$\begin{array}{l}\text { Bank } \\
\text { Rakyat } \\
\text { Indonesia } \\
\text { Syariah } \\
\text { (BRI S) }\end{array}$} & 2012 & $11.35 \%$ & $3.00 \%$ & $1.19 \%$ & $86.63 \%$ & $103.07 \%$ \\
\hline & 2013 & $14.49 \%$ & $4.06 \%$ & $1.15 \%$ & $95.24 \%$ & $102.70 \%$ \\
\hline & 2014 & $12.89 \%$ & $4.60 \%$ & $0.08 \%$ & $99.97 \%$ & $93.90 \%$ \\
\hline & 2015 & $13.94 \%$ & $4.86 \%$ & $0.76 \%$ & $93.79 \%$ & $84.16 \%$ \\
\hline & 2016 & $20.63 \%$ & $4.57 \%$ & $0.95 \%$ & $91.33 \%$ & $81.42 \%$ \\
\hline
\end{tabular}

Dari tabel menunjukkan bahwa kinerja keuangan bank syariah untuk masing-masing rasio keuangan berfluktuasi, sebagaimana halnya dengan bank konvensional. Pada rasio permodalan bank syariah berada diatas standar yang telah ditetapkan oleh Bank Indonesia, hal ini berarti bank syariah mempunyai permodalan yang mencukupi untuk mendukung kegiatan bank secara efisien. Nilai CAR tertinggi yaitu pada bank BRI Syariah pada tahun 2016 sebesar 20.63\%, sedangkan nilai CAR paling rendah yaitu pada bank BRI Syariah tahun 2012 yaitu sebesar 11.35\%. ekspansi pembiayaan yang dilakukan oleh bank syariah dilakukan dengan tetap menjaga NPL dalam kisaran baik, yaitu nilai pada rasio ini berada dibawah 5\%. Nilai NPL tertinggi yaitu pada bank Syariah Mandiri pada tahun 2014 sebesar $6.48 \%$, sedangkan nilai NPL terendah yaitu pada bank BNI Syariah tahun 2013 dan 2014 sebesar 1.86\%.

Rentabilitas perbankan syariah yaitu pada rasio ROA berfluktuasi dan masih berada dibawah ROA bank konvensional. Nilai ROA tertinggi yaitu 
pada bank Syariah Mandiri pada tahun 2012 sebesar 2.25\%, sedangkan ROA paling rendah pada bank BRI Syariah pada tahun 2014 sebesar $0.08 \%$. Nilai rasio tertinggi BOPO yaitu pada bank BRI Syariah pada tahun 2014 sebesar 99.97\%, sedangkan BOPO paling rendah pada bank Syariah Mandiri tahun 2012 sebesar $73.00 \%$. pada rasio likuiditas yaitu pada rasio LDR bank syariah memiliki nilai tertinggi pada bank BRI Syariah pada tahun 2012 sebesar 103.07\%, sedangkan LDR paling rendah pada bank Syariah Mandiri pada tahun 2016 sebesar $79.19 \%$. Meskipun sistem yang digunakan antara bank konvensional menggunakan sistem bunga dengan bank syariah yang menggunakan sistem bagi hasil berbeda, namun nilai dari rasio keuangan yang digunakan dalam penilaian kinerja keuangan bank konvensional dan bank syariah, memiliki perbedaan nilai yang tidak terlalu besar pada masing-masing rasio keuangan. Hal ini menunjukkan bahwa persaingan antara bank konvensional dengan bank syariah semakin ketat. Sehingga baik bank konvensional maupun bank syariah harus lebih meningkatkan kinerjanya.

Uji normalitas bertujuan untuk menguji apakah dalam model regresi variabel pengganggu atau residual memiliki distribusi normal. Pengujian normalitas dapat dilakukan dengan menggunakan Kolmogorov smirnov (Ks) dengan melihat perbandingan nilai signifikasi yang dihasilkan $>0.05$ maka distribusi datanya dikatakan normal, sebaliknya jika signifikasi yang dihasilkan $<0.05$ maka data tidak terdistribusi secara normal. Hasil uji normalitas data terdapat pada tabel di bawah ini:

Tabel 7

Uji Normalitas

\begin{tabular}{llrrrrr}
\hline & \multicolumn{7}{c}{ One-Sample Kolmogorov-Smirnov Test } \\
& & CAR & NPL & ROA & BOPO & LDR \\
\hline $\mathrm{N}$ & & 30 & 30 & 30 & 30 & 30 \\
Normal & Mean & .1655 & .0301 & .0234 & .7874 & .8711 \\
Parameters,b & Std. Deviation & .02809 & .01424 & .01478 & .12587 & .06598 \\
Most Extreme & Absolute & .115 & .202 & .174 & .131 & .125 \\
Differences & Positive & .115 & .202 & .174 & .131 & .125 \\
& Negative & -.068 & -.153 & -.089 & -.127 & -.073 \\
Kolmogorov-Smirnov Z & .630 & 1.106 & .956 & .717 & .682 \\
Asymp. Sig. (2-tailed) & .822 & .173 & .321 & .682 & .741 \\
\hline a. Test distribution is Normal. & & & & & \\
b. Calculated from data. & & & & & \\
Sumber: Hasil Olahan Data SPSS, 2018 & & & & &
\end{tabular}

Dari table diatas dapat dilihat bahwa hasil uji normalitas menunjukkan bahwa nilai Asymp. Sig (2-tailed) CAR sebesar 0.822, NPL sebesar 0.173, ROA sebesar 0.321, BOPO sebesar 0.682 dan LDR sebesar 0.741 maka didtribusi data yang digunakan dalam penelitian ini adalah normal, karena Asymp. Sig (2-tailed) untuk masing-masing rasio keuangan lebih besar dari 0.05 . 
Tabel 8

Uji Beda Dua Rata-rata (Independent Sample T-Test) Bank Konvensional dan Bank Syariah

Independent Samples Test

\begin{tabular}{|c|c|c|c|c|c|c|c|c|}
\hline & & $\begin{array}{l}\text { Levene's T } \\
\text { Equality of } \\
\text { Variances }\end{array}$ & est for & t-test fo & r Equalit & ty of Mear & & \\
\hline & & $\mathrm{F}$ & Sig. & $\mathrm{T}$ & df & $\begin{array}{l}\text { Sig. } \\
\text { (2-tailed } \\
\text { ) }\end{array}$ & $\begin{array}{l}\text { Mean } \\
\text { Differe } \\
\text { nce }\end{array}$ & $\begin{array}{l}\text { Std. Error } \\
\text { Differenc } \\
\mathrm{e}\end{array}$ \\
\hline \multirow[t]{2}{*}{ CAR } & $\begin{array}{l}\text { Equal variances } \\
\text { assumed }\end{array}$ & .028 & .867 & 3.171 & 28 & .004 & .02839 & .00895 \\
\hline & $\begin{array}{l}\text { Equal variances } \\
\text { not assumed }\end{array}$ & & & 3.171 & 27.927 & .004 & .02839 & .00895 \\
\hline \multirow[t]{2}{*}{ NPL } & $\begin{array}{l}\text { Equal variances } \\
\text { assumed }\end{array}$ & 12.726 & .001 & -3.755 & 28 & .001 & -.01621 & .00432 \\
\hline & $\begin{array}{l}\text { Equal variances } \\
\text { not assumed }\end{array}$ & & & -3.755 & 19.078 & .001 & -.01621 & .00432 \\
\hline \multirow[t]{2}{*}{ ROA } & $\begin{array}{l}\text { Equal variances } \\
\text { assumed }\end{array}$ & 1.677 & .206 & 9.124 & 28 & .000 & .02514 & .00276 \\
\hline & $\begin{array}{l}\text { Equal variances } \\
\text { not assumed }\end{array}$ & & & 9.124 & 23.704 & .000 & .02514 & .00276 \\
\hline \multirow[t]{2}{*}{$\begin{array}{l}\text { BOP } \\
\text { O }\end{array}$} & $\begin{array}{l}\text { Equal variances } \\
\text { assumed }\end{array}$ & .884 & .355 & -9.260 & 28 & .000 & -.21490 & .02321 \\
\hline & $\begin{array}{l}\text { Equal variances } \\
\text { not assumed }\end{array}$ & & & -9.260 & 26.918 & .000 & -.21490 & .02321 \\
\hline \multirow[t]{2}{*}{ LDR } & $\begin{array}{l}\text { Equal variances } \\
\text { assumed }\end{array}$ & 7.994 & .009 & -2.216 & 28 & .035 & -.05012 & .02261 \\
\hline & $\begin{array}{l}\text { Equal variances } \\
\text { not assumed }\end{array}$ & & & -2.216 & 21.159 & .038 & -.05012 & .02261 \\
\hline
\end{tabular}

Capital Adequacy Ratio (CAR)

Dari tabel diatas $\mathrm{F}$ hitung CAR dengan Equal variance assumed (diasumsi kedua varians sama) adalah 0.028 dengan signifikansi 0.867 . Oleh karena itu signifikansi data diatas lebih besar dari 0.05, maka dapat dikatakan tidak terdapat perbedaan varians pada data perbandingan kinerja kauangan bank konvensional dengan bank syariah jika dilihat dari Rasio CAR. Apabila kedua varians sama, maka dasar yang digunakan Equal variance assumed (diasumsi kedua varians sama). T hitung untuk CAR adalah 3.171 dengan signifikansi sebesar 0.004. Karena nilai sig. $t$ hitung $<\mathrm{t}$ tabel yaitu $0.004<$ 0.05 maka dapat dikatakan bahwasannya terdapat perbedaan yang signifikan antara bank konvensional dengan bank syariah jika dilihat dari rasio CAR Non Performing Loan (NPL) 
Jika dilihat dari tabel diatas F hitung NPL dengan Equal variance assumed (diasumsi kedua varians sama) adalah 12.726 dengan tingkat signifikansi 0.001 , maka dapat dikatakan bahwa terdapat perbedaan varians pada data perbandingan kinerja keuangan bank konvensional dengan bank syariah untuk rasio NPL. Apabila kedua varians berbeda, maka dasar yang digunakan Equal variance not assumed (diasumsi kedua varians berbeda). T hitung untuk NPL adalah -3.755 dengan signifikansi sebesar 0.001. Karena nilai sig. $t$ hitung $<\mathrm{t}$ tabel yaitu $0.001<0.05$ maka dikatakan bahwa terdapat perbedaan yang signifikan antara bank konvensional dengan bank syariah jika dilihat dari rasio NPL.

Return on Asset (ROA)

Dilihat dari tabel diatas $\mathrm{F}$ hitung ROA dengan Equal variance assumed (diasumsi kedua varians sama) adalah 1.677 dengan signifikansi 0.206. Karena tingkat signifikansi data diatas lebih besar dari 0.05 , maka dapat dikatakan bahwa tidak terdapat perbedaan varians pada data perbandingan kinerja keuangan antara bank konvensional dengan bank syariah untuk rasio ROA. Apabila kedua varians sama, maka dasar yang digunakan Equal variance assumed (diasumsi kedua varians sama). T hitung untuk ROA adalah 9.124 dengan tingkat signifikansi sebesar 0.000. Karena nilai sig. $\mathrm{t}$ hitung $<\mathrm{t}$ tabel yaitu $0.000<0.05$ maka dapat dikatakan bahwa terdapat perbedaan yang signifikan antara bank konvensional dengan bank syariah jika dilihat dari rasio ROA.

Beban Operasional dibagi Pendapatan Operasional (BOPO)

Dilihat dari tabel diatas $\mathrm{F}$ hitung BOPO dengan Equal variance assumed (diasumsi kedua varians sama) adalah 0.884 dengan signifikansi 0.355. Karena tingkat signifikansi data diatas lebih besar dari 0.05, maka dapat dikatakan bahwa tidak terdapat perbedaan varians pada data perbandingan kinerja keuangan antara bank konvensional dengan bank syariah untuk rasio BOPO. Apabila kedua varians sama, maka dasar yang digunakan Equal variance assumed (diasumsi kedua varians sama). T hitung untuk BOPO adalah -9.260 dengan tingkat signifikansi sebesar 0.000. Karena nilai sig. $\mathrm{t}$ hitung $<\mathrm{t}$ tabel yaitu $0.000<0.05$ maka dapat dikatakan bahwa terdapat perbedaan yang signifikan antara bank konvensional dengan bank syariah jika dilihat dari rasio BOPO.

Loan to Deposit Ratio (LDR)

Jika dilihat dari tabel diatas $\mathrm{F}$ hitng LDR dengan Equal variance assumed (diasumsi kedua varians sama) adalah 7.994 dengan tingkat signifikansi 0.009 , maka dapat dikatakan bahwa terdapat perbedaan varians pada data perbandingan kinerja keuangan bank konvensional dengan bank syariah untuk rasio LDR. Apabila kedua varians berbeda, maka dasar yang digunakan Equal variance not assumed (diasumsi kedua varians berbeda). T hitung untuk LDR adalah -2.216 dengan signifikansi sebesar 0.036. Karena nilai sig. $t$ hitung $<\mathrm{t}$ tabel yaitu $0.036<0.05$ maka dikatakan bahwa terdapat perbedaan yang signifikan antara bank konvensional dengan bank syariah jika dilihat dari rasio LDR.

Hal ini mendukung hasil penelitian Solikah et al., (2017), yang menyatakan terdapat perbedaan yang signifikan untuk rasio CAR, BOPO dan LDR antara kinerja keuangan bank konvensional dengan bank syariah. 
Sedangkan untuk ROA dan NPL tidak terdapat perbedaan yang signifikan antara kinerja keuangan bank konvensional dengan bank syariah. Budiartini et al., (2017) (Suhartono \& Yusra, 2019), yang menyatakan terdapat perbedaan yang signifikan untuk rasio CAR, NPM/NPL, ROA, BOPO dan LDR antara kinerja keuangan bank konvensional dengan bank syariah. Komardi \& Silalahi, (2017) yang menyatakan terdapat perbedaan yang signifikan untuk rasio CAR, BOPO, ROA dan NPL antara kinerja keuangan bank konvensional dengan bank syariah. Sedangkan untuk LDR tidak terdapat perbedaan yang signifikan antara kinerja keuangan bank konvensional dengan bank syariah.

\section{KESIMPULAN}

Berdasarkan hasil statistik uji independent sample t-test (uji beda dua rata-rata), diperoleh bahwa terdapat perbedaan secara signifikan antara kinerja keuangan bank konvensional dengan bank syariah yaitu rasio CAR $0.004<0.05$, NPL $0.001<0.05$, ROA yaitu $0.000<0.05$, BOPO $0.000<0.05$ dan LDR $0.036<0.05$, ini dikarenakan niali sig. t hitung $<\mathrm{t}$ tabel. Berdasarkan perbandingan analisis rasio keuangan kinerja keuangan bank konvensional lebih baik dari segi rasio CAR, NPL, ROA dan BOPO sedangkan kinerja keuangan bank syariah lebih baik dari segi rasio LDR.

\section{UCAPAN TERIMA KASIH}

Terima kasih peneliti sampaikan kepada:

1. Bapak Febryandhie Ananda, SE, M.Si selaku ketua STIE "KBP” Padang yang telah memberikan fasilitas dan kemudahan kepada penulis sehingga studinya dapat berjalan dengan lancar.

2. Ibu Lidya Martha, SE, MM selaku wakil ketua STIE “KBP” Padang.

3. Ibu Afriyeni, SE, MM selaku direktur AKBP Padang.

4. Ibu Febsri Susanti, SE, MM selaku Ketua Program Studi Manajemen Sekolah Tinggi Ilmu Ekonomi “Keuangan, Perbankan dan Pembangunan” Padang.

5. Ibu Lidya Martha, SE, MM selaku Dosen Pembimbing penulis, yang telah membimbing penulis dengan penuh kesabaran dari awal proposal sampai saat sekarang ini.

6. Ibu Aminar Sutra Dewi, SE, MM selaku Dosen Pembimbing Akademik.

7. Semua pihak yang telah memberikan dukungan beserta bantuannya dalam menyelesaikan skripsi ini.

\section{DAFTAR PUSTAKA}

Antonio, muhammad Syafi'i. 2001. Bank Syariah Dari Teori ke Praktik. Gema Insani Press. Jakarta.

Abdullah, A. 2008. Prestasi Belajar. (http://Spesialis_torch.com). Diakses pada tanggal 30 September 2014

Subekti, Imam., \& Widiyanti, Novi. Wulandari. (2004). Faktor-Faktor yang Berpengaruh Terhadap Audit Delay Di Indonesia. Simposium Nasional Akuntansi VII, 991-1002.

Kasmir, 2011, “Analisis Laporan Keuangan”, Raja Grafindo Persada: Jakarta. Kuswadi. 2006. Memahami Rasio-Rasio Keuangan Bagi Orang Awam. Jakarta : PT Elex Media Komputindo. 
Ningsih, W. W. (2012). Analisis Perbandingan Kinerja Keuangan Bank Umum Syariah dengan Bank Umum Konvensional di Indonesia. Universitas Hasanudin.

Sugiyono. 2011. Metode Penelitian Kuantitatif, Kualitatif dan R\&D. Bandung: Afabeta

Sujarweni, Wiratna. 2015. SPSS Untuk Penelitian. Yogyakarta : Pustaka Baru Press

Budiartini, N. K. S., Agung, A. A. P., \& Gama, A. W. S. (2017). Analaisis Perbedaan Kinerja Bank Umum Syariah dan Bank Umum Konvensional di Indonesia, 15(2009), 43-55.

Danil, A., \& Yusra, I. (2019). Pengaruh kausal antara ukuran perusahaan, nilai buku dan likuiditas saham di Bursa Efek Indonesia. INA-Rxiv.

Hanafi, D., \& Yusra, I. (2019). Tangibility, liquidity, growth opportunity, dan leverage: studi pada perusahaan terdaftar di Bursa Efek Indonesia. INA-Rxiv, (2001).

Komardi, D., \& Silalahi, E. R. (2017). Comparative Analysis of Financial Performance of Syariah Banking and Conventional Banking, 2(2), 175-183. https://doi.org/2527-8215

Kurniawan, A., \& Yusra, I. (2019). Apakah profitabilitas dan nilai buku berdampak terhadap return saham?: studi empiris pada perusahaan LQ45. INA-Rxiv.

Ningsih, widya wahyu. (2012). Analisis perbandingan kinerja keuangan bank umum syariah dengan bank umum konvensional di indonesia skripsi.

Solikah, H. M., Mardani, R. M., \& Wohono, B. (2017). Analisis Perbandingan Kinerja Keuangan Bank Umum Syariah dengan Bank Umum konvensional di Indonesia (Studi Empiris pada Perusahaan Perbankan di Bursa Efek Indonesia), 07(17), 20-32.

Suhartono, \& Yusra, I. (2019). Analisis perbandingan kinerja keuangan bank konvensional dengan bank syariah yang terdaftar di BEI. INA-Rxiv, 1-9.

Yusra, I. (2016). Kemampuan Rasio Likuiditas dan Solvabilitas dalam Memprediksi Laba Perusahaan: Studi Empiris pada Perusahaan Telekomunikasi yang Terdaftar di Bursa Efek Indonesia. Jurnal Benefita, 1(1), 33-42. https://doi.org/http://dx.doi.org/10.22216/jbe.v1i1.878

Yusra, I., Hadya, R., \& Fernandes, J. (2017). Likuiditas , financial leverage , dan prediktabilitas beta: pendekatan Fowler and Rorke sebagai metode koreksi Beta. Jurnal Benefita, 2(1), 81-91.

Yusuf, D., \& Yusra, I. (2019). Faktor-faktor yang mempengaruhi struktur modal perusahaan. INA-Rxiv. 